\title{
Evaluating Presidencies of the Council of the EU. Revisiting Nice
}

Citation for published version (APA):

Schout, A., \& Vanhoonacker, S. M. R. L. (2006). Evaluating Presidencies of the Council of the EU. Revisiting Nice. Journal of Common Market Studies, 44, 1051-1077. https://doi.org/10.1111/j.14685965.2006.00673.x

Document status and date:

Published: 01/01/2006

DOI:

10.1111/j.1468-5965.2006.00673.x

Document Version:

Publisher's PDF, also known as Version of record

\section{Document license:}

Taverne

\section{Please check the document version of this publication:}

- A submitted manuscript is the version of the article upon submission and before peer-review. There can be important differences between the submitted version and the official published version of record.

People interested in the research are advised to contact the author for the final version of the publication, or visit the DOI to the publisher's website.

- The final author version and the galley proof are versions of the publication after peer review.

- The final published version features the final layout of the paper including the volume, issue and page numbers.

Link to publication

\footnotetext{
General rights rights.

- You may freely distribute the URL identifying the publication in the public portal. please follow below link for the End User Agreement:

www.umlib.nl/taverne-license

Take down policy

If you believe that this document breaches copyright please contact us at:

repository@maastrichtuniversity.nl

providing details and we will investigate your claim.
}

Copyright and moral rights for the publications made accessible in the public portal are retained by the authors and/or other copyright owners and it is a condition of accessing publications that users recognise and abide by the legal requirements associated with these

- Users may download and print one copy of any publication from the public portal for the purpose of private study or research.

- You may not further distribute the material or use it for any profit-making activity or commercial gain

If the publication is distributed under the terms of Article $25 \mathrm{fa}$ of the Dutch Copyright Act, indicated by the "Taverne" license above, 


\title{
Evaluating Presidencies of the Council of the EU: Revisiting Nice*
}

\author{
ADRIAAN SCHOUT \\ European Institute of Public Administration and Clingendael European Studies Programme \\ SOPHIE VANHOONACKER \\ University of Maastricht
}

\begin{abstract}
Judging presidencies is easy, evaluating them is not. Evaluations are rare and often superficial. This article provides a theoretical framework for such evaluations. Using contingency theory, it develops hypotheses about the demand for, and supply of, presidency roles. It offers a structured analysis by linking behaviour to the specificities of the actual negotiations. The framework is then applied to the performance of the French presidency during the IGC in 2000. The analysis shows, that apart from the complaints relating to some embarrassing failures, not all the criticism levelled at the French was justified.
\end{abstract}

\section{Introduction: Towards a Contingency Theory for the Presidency}

Despite the centrality of the Council presidency in EU decision-making, it is surprising to see so little systematic analysis of Member States' performance in the chair. Presidencies are evaluated in the national and international media after their turn in office but have received little attention from scholars. Among others, the JCMS publishes yearly overviews. Useful as they are, these reports are short and do little more than list the major developments (e.g. Barbé, 2003; Friis, 2003). Moreover, definitions of success are, for the most part, only loosely presented. Dimitrakopoulos and Pappas refer to the ability to 'increase the pace of integration' and 'to manage political divergence' (2004, p. 45).

\footnotetext{
* The authors are grateful to Desmond Dinan, Ole Elgström, Rudi Wurzel and the anonymous referees for their comments. 
Quaglia (2004, p. 50) points to the realization of 'considerable progress'. An evaluation has to go beyond such general statements. In some cases success may be hardly related to the presidency, while on other occasions a chair may have performed well, even if there is little progress to report.

There is both an academic and a practical need to deepen understanding of the behaviour of presidencies. Despite the new stream of EU studies devoted to the subtleties of the presidency as a broker and initiator (e.g. Tallberg, 2003; Elgström, 2003), conceptualization of its behaviour is still seminal. With no theory of the presidency there is a deficiency in our understanding of EU decision-making. From a practical perspective, insight into the behaviour is needed to prevent the weaknesses that are haunting presidencies. Upcoming presidencies miss opportunities to learn from their predecessors. Moreover, lack of evaluation implies fewer checks and balances.

The Trumpf Piris report (March 1999) initiated debates surrounding more professional and effective management of the Council. The future of the presidency was also an important theme of discussion in the Convention, but in the end the constitution maintained the rotating chair for most Council configurations except for the European Council and the Foreign Affairs Council. Following the French and Dutch 'no', even these changes have become uncertain. Therefore, the governance of this actor in an enlarged Union continues to be relevant as is the search for mechanisms to support and, through this, steer presidencies in a better way. Closer co-operation amongst succeeding presidencies or so-called team presidencies is one way to stimulate peer pressure, but it remains to be seen whether this will work in practice. In addition, ex post evaluations (naming and shaming) as a 'new governance' mechanism may stimulate better performance (Schout, 2004). This, however, presupposes a good understanding of the roles of the chair and its performance.

Using contingency theory, this article elaborates a framework for evaluating the presidency. This requires making its roles explicit. Four roles are identified (organizer, broker, political leader and national representative) and linked to the conditions of the environment in which the chair operates. The assumption is that it is the situation that dictates which roles are needed. A set of hypotheses are formulated regarding the relationship between behaviour and environmental circumstances. They address the internal and external situational variables that influence the behaviour of the chair. External conditions, i.e. pressures from outside the country holding the presidency, 'demand' specific roles. The internal presidency environment influences the 'supply' of roles. By comparing behaviour and needs, this contingency theory offers a tool to assess the performance of the chair.

The theory is used to evaluate the behaviour of the French presidency during the Intergovernmental Conference (IGC) of 2000. The situational variables that 
played a role in all four items on the IGC agenda are examined: flexibility, the extension of qualified majority voting (QMV), the composition of the Commission and the reweighting of votes. For each item we examine whether the presidency supplied the appropriate roles. Nice is particularly interesting as the French were severely criticized for being badly organized, biased, spoiling the atmosphere and lacking initiative (see below).

A number of caveats are in order when elaborating a framework for evaluation. Firstly, this article presents a single sample case study of one presidency in a specific context. $\mathrm{N}=1$ studies do allow the testing and constructing of theories, but one has to be careful when generalizing the findings (King et al., 1994). The specific setting of an IGC demands extra caution. Opinions may vary on whether IGC negotiations differ from other sensitive negotiations, especially when it comes to the role of the presidency. However, whether it be in a technical Council, a European Council or an IGC, the roles of the chair will depend on the situation at hand and juggling between them will be imperative (Schout, 1998). Secondly, contingency theory, although it helps to separate supply and demand factors, cannot prevent a degree of subjectivity, as ultimately judgements have to be made on whether supply matched demand. The interviews and other information used in this study revealed strong opinions. Using the framework elaborated below and by consulting a variety of sources and voices, we hope to have moved beyond heated accounts. To reduce the risk of subjectivity we presented the findings from the study to several of our interviewees. ${ }^{1}$

To develop the contingency theory, the four roles of the chair are first defined in Section I. Section II identifies hypotheses regarding the external and internal forces that influence the demand and supply of the roles. Finally, the model is applied to the French presidency (Section III). The conclusions discuss the relevance of the approach for understanding presidencies.

\section{Presidency Roles}

Discussing the roles of the presidency is not a trivial matter (see, e.g., Elgström, 2002). The office developed over time and in different directions (O'Nuallain, 1985). Emerging gaps in the EU's institutional design demanded organizational as well as political responsibilities from the presidency. Nowadays, most scholars mention the following tasks: management of day-to-day Council business,

\footnotetext{
${ }^{1}$ The research is based on reports, books, articles, presidency papers and interviews with key actors in the negotiations. Senior officials were interviewed from the European Commission; General Secretariat of the Council; Permanent Representations (Dutch, Portuguese, Finnish and French); Ministries for Foreign Affairs (Belgian, Dutch and French); and the French Prime Minister's office. Several of the interviewees have commented on earlier drafts to ensure a balanced assessment.
} 
co-ordination, chairing, mediation, spokesperson and external representation, acting as contact point, and taking political initiatives (e.g. Kirchner, 1992; Westlake, 1999; Hayes-Renshaw and Wallace, 1997; Sherrington, 2000; Tallberg, 2003; Elgström, 2003; Wurzel, 2004). This list can be presented at different levels of detail (see, e.g., the Council Guide, 1997). To get at the essence of the presidency, we group the various tasks into a limited number of roles. This was also the approach of the Three Wise Men in their report on the reform of the institutions (1979). They referred to the "dual role of organizational control and political impetus' (p. 35). In addition, we distinguish the roles of broker and representative of the national position/interests. This leads to a more complex set of roles that the presidency has to juggle (Schout, 1998). Sometimes there is a balanced package of roles; in other cases one or more roles will dominate.

These roles have specific conceptual origins (Schout and Vanhoonacker, 2005). The first three relate to three key roles in leadership theory (see Yukl, 1998): task-oriented leadership, group-oriented leadership and transformational leadership. The way in which Yukl elaborates these types of leadership comes very close to what we present as the tasks that have to be performed in relation to the organizer, broker and political leadership roles (Table 1). Taskoriented leadership is about taking the steps necessary to get a job done. This role is very demanding, but also, if all goes well, hardly noticed. However, if neglected - e.g. if papers are too late - it may greatly hamper the meeting and cause much frustration. Group-oriented leadership involves sounding out positions, creating a good atmosphere and unearthing directions for compromises. Brokerage requires trust. Knowing the positions and building relationships may require long-term preparations. This role is not exclusive. Usually, multiple brokerage capacities involve the Commission, the Council General Secretariat (particularly in the case of an IGC) and other delegations. Task-oriented leadership and group-oriented leadership aim at getting results and serving group processes. As one member of a presidency team said: 'I don't mind whether they decide to paint the room black or white, as long as the decision is taken in the correct way'.

Transformational leadership goes beyond arriving at just any common position. It is long term oriented and aims at finding new solutions. This presidency role is particularly relevant when proposals require rethinking traditional values and when interests threaten long-term viability.

Representation of national positions and interests, even though it is controversial (Ludlow, 1995), also needs to be included. It is an illusion to assume that countries at the helm can ignore their interests (e.g. Dinan, 1999, p. 240). The question is not whether a chair has preferences but how it handles them (Tallberg, 2003). Negotiation literature underlines that being fair is more 
Table 1: Presidency Roles

\begin{tabular}{|c|c|c|c|c|}
\hline & Organizer & Broker & $\begin{array}{l}\text { Political } \\
\text { Leadership }\end{array}$ & $\begin{array}{c}\text { National Positions/ } \\
\text { Interests }\end{array}$ \\
\hline $\begin{array}{l}\text { Conceptual } \\
\text { origin }\end{array}$ & $\begin{array}{l}\text { Task-oriented } \\
\text { leadership }\end{array}$ & $\begin{array}{l}\text { Group-oriented } \\
\text { leadership }\end{array}$ & $\begin{array}{l}\text { Transformational } \\
\text { leadership }\end{array}$ & $\begin{array}{l}\text { Traditional role of } \\
\text { Member States in } \\
\text { negotiations }\end{array}$ \\
\hline \multirow[t]{9}{*}{ Tasks } & $\begin{array}{l}\text { Planning } \\
\text { meetings } \\
\text { External } \\
\text { representation }\end{array}$ & $\begin{array}{l}\text { Sounding out } \\
\text { Member States }\end{array}$ & $\begin{array}{l}\text { Putting current } \\
\text { discussions in a } \\
\text { long-term } \\
\text { perspective } \\
\text { of EU challenges }\end{array}$ & $\begin{array}{l}\text { Short-term } \\
\text { orientation on } \\
\text { national gains and } \\
\text { values }\end{array}$ \\
\hline & $\begin{array}{l}\text { Arranging } \\
\text { rooms }\end{array}$ & $\begin{array}{l}\text { Creating a good } \\
\text { atmosphere }\end{array}$ & $\begin{array}{l}\text { Steering the } \\
\text { debate in } \\
\text { specific } \\
\text { directions }\end{array}$ & $\begin{array}{l}\text { Influencing the } \\
\text { political agenda } \\
\text { by adding or } \\
\text { removing topics }\end{array}$ \\
\hline & $\begin{array}{l}\text { Drafting } \\
\text { agendas of } \\
\text { meetings } \\
\text { (listing the }\end{array}$ & $\begin{array}{l}\text { Creating } \\
\text { understanding } \\
\text { for each other's } \\
\text { problems }\end{array}$ & $\begin{array}{l}\text { Convincing } \\
\text { delegations to } \\
\text { abandon short- } \\
\text { term interests }\end{array}$ & \\
\hline & agenda items) & $\begin{array}{l}\text { Identifying } \\
\text { mainstreams }\end{array}$ & Not necessarily & \\
\hline & $\begin{array}{l}\text { Chairing } \\
\text { meetings (i.e. } \\
\text { organizing the } \\
\text { debates) }\end{array}$ & $\begin{array}{l}\text { Identifying } \\
\text { bargains } \\
\text { and trade-offs }\end{array}$ & $\begin{array}{l}\text { moving towards } \\
\text { new vistas for the } \\
\text { EU, but at least } \\
\text { moving away } \\
\text { from frictions by }\end{array}$ & \\
\hline & $\begin{array}{l}\text { Preparing and } \\
\text { distributing } \\
\text { documents }\end{array}$ & $\begin{array}{l}\text { Formulating } \\
\text { compromises }\end{array}$ & $\begin{array}{l}\text { recasting the } \\
\text { debate in a long- } \\
\text { term perspective }\end{array}$ & \\
\hline & $\begin{array}{l}\text { Mapping the } \\
\text { various aspects } \\
\text { of the topic }\end{array}$ & $\begin{array}{l}\text { Serving group } \\
\text { processes }\end{array}$ & & \\
\hline & $\begin{array}{l}\text { Separating the } \\
\text { issues, devising a } \\
\text { strategy for } \\
\text { moving forward }\end{array}$ & & & \\
\hline & $\begin{array}{l}\text { Carrying out } \\
\text { background studies }\end{array}$ & & & \\
\hline Focus & $\begin{array}{l}\text { Efficiency in the } \\
\text { search for a } \\
\text { common } \\
\text { position }\end{array}$ & $\begin{array}{l}\text { Fairness in the } \\
\text { search for a } \\
\text { common position } \\
\text { (guarding trust) }\end{array}$ & $\begin{array}{l}\text { Moving towards } \\
\text { long-term } \\
\text { objectives }\end{array}$ & $\begin{array}{l}\text { Preventing high } \\
\text { (political) costs at } \\
\text { the national level }\end{array}$ \\
\hline
\end{tabular}

Source: Schout and Vanhoonacker (2005). 
important than being neutral (Gibson et al., 1996). In the EU context, it is particularly interesting to look at the interaction between the chair and its national delegation.

Table 1 presents a summary of the four roles (for details, see Schout and Vanhoonacker, 2005). This classification calls for qualifications. Firstly, the boundaries between the roles are not always well defined. The investments in the first three roles can be highly influenced by the chair's national interests. However, we consider this role separately in order to examine explicitly how it affected the chair's performance. Secondly, the roles can be mutually supportive as well as conflicting. Political leadership generally requires the organizer and broker roles to ensure that the necessary homework is done and to build support from Member States. However, transformational leadership may well spoil the atmosphere if, for whatever reason, the chair is not trusted or if one or more countries feel steam-rollered into new policies. Thirdly, the fact that they are interrelated also implies that the presidency team - including the national delegate - has different roles at the same time (Wurzel, 2004). Finally, not all roles are relevant in every dossier. Similarly, the chair's role cannot be reduced to one of mere broker.

\section{A Contingency Theory for the Presidency}

That there is no single 'best way' to organize a presidency is a view that has triggered research on relations between specific types of complexity and the way in which organizations are structured or behave (Lawrence and Lorsch, 1969; Galbraith, 1973). Environmental conditions may 'demand' certain types of behaviour. It is important to state early on that the resulting body of contingency theory does not lead to fixed patterns. There are many overlapping and conflicting environmental variables that pull organizations in different directions. Moreover, there is an element of choice (Child, 1972, 1975). Different strategists have different preferences, and well-chosen actions can change the characteristics of the environment. Hence, structures and behaviours are influenced by external conditions (demand, $D$ ) and are shaped by the roles the organization chooses rationally (supply, $S$ ) (see also the logic of expected consequences in Elgström, 2003, p. 10). Due to these options, contingency theory cannot predict or prescribe organizational behaviour. Nor is contingency theory sufficient for examining empirical phenomena. However, it can indicate which patterns will be feasible under specific circumstances. Therefore, contingency theory does not lead to a set of cast-iron rules, but offers a framework for mapping relevant variables and causalities to support planning and evaluations. 


\section{An Effective Presidency: $D=S$}

Because of the complexity of 'effectiveness', performance evaluations are inherently multi-dimensional (e.g. Powell, 1987). There are many definitions of an effective chair such as: one that concludes negotiations, ensures that the outcome meets quality standards (e.g. of legal clarity), maintains a good atmosphere, or one that achieves its objectives. Each of these definitions is hard to substantiate, as outcomes relate to many factors, such as efforts of previous presidencies, sensitivities, the Commission's flexibility, personal styles, etc.

Contingency theory explicitly brings the outside environment into discussions on presidency behaviour. The assumption is that, depending on the circumstances, different roles will be demanded and be effective. At the same time, the roles supplied will be influenced by internal contingencies. Hence, contingency theory leads to a particular definition of an effective chair: one that matches the demand and supply of presidency roles. For example, a presidency will be counterproductive if brokerage is needed while the chair focuses only on national interests. There may also be circumstances in which a national position will not be problematic (see below). Even though there is no direct link with the output of Council meetings, following the logic of contingency theory, a presidency providing the required roles will at least make it easier to reach agreement. The advantage of the $D=S$ definition of effectiveness is that it captures a set of input and output elements and thus leads to a multivariate analysis.

\section{Contingency Factors}

The contingency approach requires specification of the factors that influence the demand and supply of roles. It is also necessary to identify the forces that help to align supply and demand. Tables 2 and 3 present the external and internal factors that steer the demand and supply of the roles. External contingencies refer to the EU context that exerts pulls on the chair (e.g. towards a specific type of leadership). Internal contingencies relate to the domestic environment that pushes it in certain directions. The pulls may emphasize the need for one particular role (the 'dominant demand'). In some situations there is in fact only one important contribution the chair can make, e.g. to broker when situations are really tight. Similarly, the internal contingencies may push for a specific 'dominant supply'.

The external variables included in this study are: the degree to which a topic has been explored (new versus old), the level of trust in the chair, the presence of other brokers in the system, the shadow of the future, and the political 
Table 2: External Contingency Factors: The Demand for Roles

\begin{tabular}{|c|c|c|c|c|}
\hline & Organizer & Broker & Political Leadership & $\begin{array}{l}\text { National Positions/ } \\
\text { Interests }\end{array}$ \\
\hline \multicolumn{5}{|l|}{$\begin{array}{l}\text { 1. Degree to which a } \\
\text { topic has been } \\
\text { explored }\end{array}$} \\
\hline $\begin{array}{l}\text { (a) } \mathrm{Old} / \text { transparent } \\
\text { topic }\end{array}$ & $\begin{array}{l}\quad- \\
\text { Issues and positions are } \\
\text { already mapped out }\end{array}$ & $\begin{array}{l}\stackrel{-}{\text { Well known positions }} \\
\text { facilitate formulation } \\
\text { of bargains }\end{array}$ & $\begin{array}{l}\stackrel{-}{\text { Little room for }} \\
\text { novel solutions }\end{array}$ & $\begin{array}{l}\quad+ \\
\text { Position of country at } \\
\text { helm is well known }\end{array}$ \\
\hline (b) New topic & $\begin{array}{l}\quad+ \\
\text { Need to study key } \\
\text { issues and alternatives }\end{array}$ & $\begin{array}{l}\stackrel{+}{\text { Need to identify }} \\
\text { possible bargains }\end{array}$ & $\begin{array}{l}\quad+ \\
\text { Scope for steering debates } \\
\text { away from short-term } \\
\text { interests }\end{array}$ & $\begin{array}{l}\stackrel{+}{\text { Future chairs need }} \\
\text { to know all positions }\end{array}$ \\
\hline $\begin{array}{l}\text { 2. Lack of trust in } \\
\text { the chair }\end{array}$ & $\begin{array}{l}\quad \stackrel{+}{\text { Good organization can }} \\
\text { contribute to spotting distrust } \\
\text { and preventing making it } \\
\text { worse. Otherwise, } \\
\text { misunderstandings } \\
\text { may easily arise }\end{array}$ & $\begin{array}{l}\quad+ \\
\text { Extra care is needed to } \\
\text { display transparent } \\
\text { brokerage }\end{array}$ & 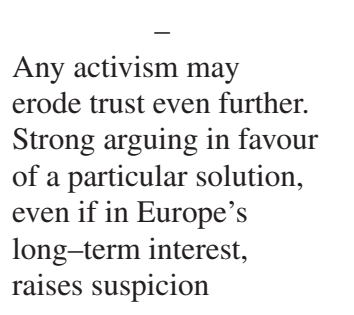 & \begin{tabular}{l}
\multicolumn{1}{c}{-} \\
Representation and \\
defence of national \\
interests further \\
reduce trust
\end{tabular} \\
\hline 3. Multiple brokerage & $\begin{array}{l}\quad- \\
\text { Others play a role in } \\
\text { mapping out issues }\end{array}$ & $\begin{array}{l}\stackrel{-}{\text { Other players }} \\
\text { compensate for the lack } \\
\text { of brokerage by the chair }\end{array}$ & $\begin{array}{l}\qquad- \\
\text { Others may put the } \\
\text { debate in a long-term/ } \\
\text { European perspective }\end{array}$ & $\begin{array}{l}\stackrel{+}{\text { Others can defend }} \\
\text { the general interest }\end{array}$ \\
\hline
\end{tabular}


Table 2: External Contingency Factors: The Demand for Roles (Contd)

\begin{tabular}{|c|c|c|c|c|}
\hline & Organizer & Broker & Political Leadership & $\begin{array}{l}\text { National Positions/ } \\
\text { Interests }\end{array}$ \\
\hline $\begin{array}{l}\text { 4. Shadow of the } \\
\text { future }\end{array}$ & $\begin{array}{l}\stackrel{+}{\text { Efficient use of valuable }} \\
\text { time is needed }\end{array}$ & $\begin{array}{l}\qquad+ \\
\text { Pressure to reach } \\
\text { agreement leads to } \\
\text { a high demand for } \\
\text { brokerage }\end{array}$ & $\begin{array}{l}\qquad+ \text { or }- \\
\text { It will depend on other } \\
\text { factors whether or not } \\
\text { political leadership will } \\
\text { be needed }\end{array}$ & $\begin{array}{l}\quad- \\
\text { Pushing for national } \\
\text { interest will further } \\
\text { complicate the } \\
\text { negotiation process }\end{array}$ \\
\hline $\begin{array}{l}\text { 5. Political sensitivity } \\
\text { (a) Non-sensitive } \\
\text { issue }\end{array}$ & $\begin{array}{l}\text { It will be easy to map out } \\
\text { the various positions }\end{array}$ & $\begin{array}{l}\qquad- \\
\text { Lack of sensitivity } \\
\text { makes it easier } \\
\text { to find a compromise }\end{array}$ & $\begin{array}{l}\qquad+ \\
\text { Countries are more willing } \\
\text { to move away from their } \\
\text { short-term national interests }\end{array}$ & $\begin{array}{l}\stackrel{+}{\text { Other delegations are }} \\
\text { more open to } \\
\text { national interests }\end{array}$ \\
\hline (b) Sensitive issue & $\begin{array}{l}\stackrel{+}{\text { Bad organization will add }} \\
\text { to further irritation }\end{array}$ & $\begin{array}{l}\qquad+ \\
\text { Building a good } \\
\text { atmosphere and } \\
\text { compromise-building } \\
\text { are crucial }\end{array}$ & $\begin{array}{l}\qquad+ \text { or }- \\
\text { Recasting the debate } \\
\text { towards long-term } \\
\text { European interests may } \\
\text { be possible but difficult }\end{array}$ & $\begin{array}{l}\qquad- \\
\text { Defence of national interest } \\
\text { will further complicate the } \\
\text { negotiations }\end{array}$ \\
\hline
\end{tabular}

Source: Authors' own data.

Notes: - : Role not relevant or to be avoided. + : Role will be needed. (As regards national interests: the environment does not demand national interests, but in some cases the environment leaves scope to include the national interest in the negotiations.) As explained in the text, the variables are interdependent so that the influence as presented in the table can differ depending on the circumstances. 


\begin{tabular}{|c|c|c|c|c|}
\hline & Organizer & Broker & Political Leadership & National Positions/Interests \\
\hline $\begin{array}{l}\text { Important topic for } \\
\text { the chairing country }\end{array}$ & $\begin{array}{l}\quad \stackrel{+}{c} \text { The presidency } \\
\text { will invest in the } \\
\text { preparations }\end{array}$ & $\begin{array}{l}\stackrel{+}{\text { The presidency will }} \\
\text { formulate compromises } \\
\text { to move things forward }\end{array}$ & $\begin{array}{l}\qquad+ \\
\text { The presidency will be } \\
\text { motivated to argue its } \\
\text { position in European } \\
\text { terms }\end{array}$ & $\begin{array}{l}\stackrel{+}{\text { The presidency will try }} \\
\text { to take national interests } \\
\text { into account }\end{array}$ \\
\hline $\begin{array}{l}\text { 2. Commitments of } \\
\text { senior management and } \\
\text { politicians }\end{array}$ & $\begin{array}{l}\quad+ \\
\text { Commitment will } \\
\text { positively affect the } \\
\text { development of a } \\
\text { strategy to move } \\
\text { forward }\end{array}$ & $\begin{array}{l}\stackrel{+}{\text { Commitment will }} \\
\text { promote brokerage }\end{array}$ & $\begin{array}{l}\qquad+ \\
\text { The presidency will be } \\
\text { motivated to argue its } \\
\text { position in European } \\
\text { terms but may also be } \\
\text { simply selling or trying } \\
\text { to sell its own } \\
\text { preferred solution }\end{array}$ & $\begin{array}{l}\stackrel{1}{ }+ \\
\text { National preferences } \\
\text { increase the chances } \\
\text { that national positions } \\
\text { /interests will be defended }\end{array}$ \\
\hline 3. Preparations & $\begin{array}{l}\quad \stackrel{+}{\text { If well prepared, the }} \\
\text { efficiency of meetings } \\
\text { will increase }\end{array}$ & $\begin{array}{l}\quad+ \\
\text { Thorough preparations } \\
\text { increase the chances of } \\
\text { brokerage being } \\
\text { supplied }\end{array}$ & $\begin{array}{l}\quad+ \\
\text { Preparations are a } \\
\text { precondition for the } \\
\text { supply of } \\
\text { transformational } \\
\text { leadership }\end{array}$ & $\begin{array}{l}+ \\
\text { Explaining the national position } \\
\text { prior to the presidency period } \\
\text { will create understanding for the } \\
\text { chair's national sensitivities. }\end{array}$ \\
\hline $\begin{array}{l}\text { 4. Sensitivity between the } \\
\text { coalition partners in the } \\
\text { government }\end{array}$ & $\begin{array}{l}\quad- \\
\text { Internal fights create } \\
\text { chaos during the } \\
\text { preparations }\end{array}$ & $\begin{array}{l}\quad- \\
\text { Internal disagreements } \\
\text { negatively affect the } \\
\text { supply of brokerage }\end{array}$ & $\begin{array}{l}- \\
\text { The partners risk } \\
\text { immobilizing each other }\end{array}$ & $\begin{array}{l}\qquad+ \\
\text { The coalition partners are likely } \\
\text { to defend positions that serve } \\
\text { the national audience }\end{array}$ \\
\hline
\end{tabular}

Source: Authors' own data.

Notes: -: This role will be difficult or impossible to offer. +: This role will be possible or is likely to be offered. 
sensitivity of a topic. ${ }^{2}$ The internal variables are the importance of the topic to the country in the chair, preferences and commitments of key players, the level of preparations, and sensitivities between coalition partners.

For each of the variables we examine how it affects the demand for the four presidency roles (Table 2). Starting with the external contingency factors, we argue that a topic that has already been explored extensively (row 1a) will not be demanding in terms of leadership and will offer scope for a national position since everyone already knows where the actors, including the presidency team, stand on the issue. On the other hand, a new issue (row 1b) needs exploration of the various positions (organizer), identification of possible bargains (broker) and provides more scope for steering the debate away from short-term frictions (political leadership). Defence of national interests may be possible because, at this stage, the chair is mainly mapping out the positions for future presidencies. Low trust in the chair (row 2) will be demanding in terms of organization and brokerage, but political leadership and the defence of national interests are inappropriate in view of complicating the negotiations even further. The presence of other brokers such as the Commission, other Member States, or the General Secretariat of the Council (row 3), reduces the demand for organization, brokerage and political leadership. If others show willingness to step in for the chair, there is scope for the defence of the national position. Row 4 presents the 'shadow of the future'. A deadline or negative repercussions on the European integration process in case of failure place high demands on the chair in terms of organization and brokerage and leave little scope for national interests. This variable says little about the need for political leadership. Finally, sensitive issues (row 5b) are very demanding in terms of organization and brokerage, leaving little scope for national interests. Such issues may or may not demand a political leadership approach, but it will be difficult.

Table 3 formulates hypotheses on the internal contingency factors. When a topic is important for the country in the chair (row 1), i.e. when it is a sensitive issue in the public eye, this will stimulate the efforts put into organization, brokerage and political leadership. Moreover, the chair will try to build its national interest into the discussions. Similarly, committed high-level players may be inclined to invest in providing different types of leadership and to emphasize the national position (row 2). It is important to incorporate this dimension as it often appears that preferences and attitudes of key players are decisive elements

\footnotetext{
${ }^{2}$ Given the complexity of social and political processes, the tables of demand and supply factors are not exhaustive. The factors listed resulted from brainstorming at the start of the study about potentially relevant situational conditions for presidencies. At the end of the study, the initial causalities could be elaborated and adjusted, whereas others could be dropped as they added little to these IGC negotiations (e.g. the influence of 'unanimity' and the 'technicality' of the topic). The identification of the relevant contingency factors and the elaboration of the causalities were part of the interviews with senior national and European officials involved in this particularly IGC.
} 
in setting priorities and formulating strategies. A thorough preparation of the presidency (row 3 ) will positively affect the provision of task-oriented, grouporiented and political leadership. The preparations will help the officials to see what steps and actions have to be taken or should be avoided. Getting a good feel for limitations and opportunities will prevent over- or under-supply of the roles (cf. the logic of appropriateness, Elgström, 2003, p. 10). If this involves intensive contacts with other countries, it will also help to create understanding for the chair's national sensitivities and also create trust in how the chair will handle the negotiations (IEEP, 2005). Competing coalition partners (row 4) tend to make it difficult for the chair to provide leadership, and may lead to a competition for the strongest representation of national interests.

The rows cannot be seen in isolation. For example, the demand in the case of old sensitive topics (Table 2, rows 1a and 5) is different from the demand in relation to new sensitive issues (rows $1 \mathrm{~b}$ and 5). When analysing the behaviour of the chair, due regard for the interrelations between contingency factors is indispensable. Contingency factors can be mutually reinforcing, but may also be conflicting. For example, transparency (row 1a) and low levels of trust (row 2) provide opposing pulls. Furthermore, some variables will clearly be stronger than others ('dominant contingency factors'). Which presidency roles are most useful needs to be considered on an issue-by-issue basis. This once again underlines that contingency analysis does not assume a straitjacket, but helps to identify the strategic decisions that have to be made.

Secondly, the list of factors is not complete. There have been only a few seminal attempts to introduce a contingency approach into European integration theory (e.g. Elgström, 2000). The five demand and four supply variables below are clearly a simplification in the analysis of the EU's political and social interactions. Compared to their richness in private-sector management theory (e.g. Ansoff, 1985), contingency approaches in EU studies are still in their infancy.

\section{Drivers for $D=S$}

Contingency theory also draws attention to the mechanisms that contribute to the approximation of demand and supply. These are, applied to the presidency:

1. Rational processes: Presidency teams analyse situations, map scenarios and decide on the optimal behaviour.

2. Institutional expectations: $D$ and $S$ in EU negotiations tend to gravitate towards both the organizational and the broker role. Diplomats in EU negotiations are mostly highly aware of what behaviour is appropriate and, hence, inclined to contain the transformational pressures from ministers. 
3. Political EU pressure: Every situation puts specific pressures on the presidency. With new proposals, peers want a neutral exploration of positions (organizational role). Deadlines on the other hand demand goal orientation and provoke political involvement.

4. Personal experience: Presidency teams benefit from experience obtained in EU negotiations and may be expected to have developed a feeling for how far they can go or when to stir up the heat.

Despite these equilibrating forces there is, however, no guarantee that $D$ will be $S$ if the pulls and pushes are too strong.

\section{The 2000 IGC Revisited}

After the preparations of the Finnish and Portuguese presidencies, France chaired the final lap of the IGC. Its performance was criticized in surprisingly undiplomatic terms. The Swedish Prime Minister Göran Persson criticized the Nice summit for being organized 'à la italienne' (Le Monde, 12 December 2000). Gray and Stubb (2001), both insiders to the IGC, emphasized the lack of continuity with previous presidencies. Others criticized the chair's bias: President Chirac was accused of an 'unashamed championing of his country's own interest' (European Voice, 14-20 December 2000) and of not listening to the views of others, particularly those of the small Member States (Le Monde, 12 December 2000). The French were blamed for being arrogant, antagonizing partners, seriously hampering the search for compromises and lacking ambition. As a result, they were accused of bearing responsibility for the poor outcome (Gray and Stubb, 2001). Costa et al. (2003) stand out with a much more nuanced view, but this then triggers the question whether they were too positive. Hence, are the accusations of poor organization, bias and lack of brokerage justifiable grounds for criticizing this presidency? We will answer this question by examining whether France provided the roles that the issues on the IGC agenda required. ${ }^{3}$

\section{Flexibility}

Enhanced co-operation within the Union's institutional framework was one of the achievements of 'Amsterdam', but the conditions were very strictly defined. The IGC 2000 aimed to simplify the procedures. The biggest challenge for the flexibility dossier was to get it on the IGC agenda. The Benelux and Italy had already lobbied actively in Helsinki (December 1999), leading the Portuguese presidency (Feira, June 2000) to add it to the agenda.

\footnotetext{
${ }^{3}$ For details on the four topics see, among others, Galloway (2001), Gray and Stubb (2001) and Ludlow (2001).
} 
Demand. By the time the French took over, flexibility was, in terms of situational variables, an 'old' or 'transparent' issue. Positions were well known: a majority supported a relaxation of the conditions, but it remained a sensitive issue for Denmark, Spain and the UK (Galloway, 2001, p. 134).

Due to the transparency there was little need for task-oriented leadership. Limited brokerage was required as a majority of countries thought along the same lines. The main task consisted of convincing the opposing minority that more flexibility would not isolate them. Moreover, the presence of other brokers reduced the pressure on the presidency. Multiple brokerage and transparency also provided scope for the chair's national position.

Supply. Both parties in the cohabitation favoured more flexibility but initially opposed placing it on the agenda in order to concentrate on the three leftovers from Amsterdam. However, once it had lost this battle, France - helped by Germany and Italy - worked hard to reach a breakthrough.

The organizer and broker roles dominated. France prepared the meetings thoroughly, by presenting various papers and structuring debates around five questions. The Permanent Representative, Pierre Vimont, devoted considerable time to it during the first eight meetings of the Preparatory Group (Gray and Stubb, 2001, p. 11) and ensured a good atmosphere. 'Ring-fencing', i.e. excluding important areas such as the internal market and economic and social cohesion, was a key contribution to brokering the compromise. It confronted fears for exclusion in core policies and lifted the right of vetoing enhanced co-operation in the first and third pillars (Galloway, 2001, p. 134). The political agreement was already reached at the European summit in Biarritz (Gray and Stubb, 2001, p. 12).

$D=S$ ? Flexibility did not place huge demands on the chair. The positions were well known (transparency), there was multiple brokerage and although the relaxation of the flexibility conditions struck a sensitive chord with some countries, it was not a major issue in the IGC. There was some demand for brokerage which the chair provided.

\section{Qualified Majority Voting (QMV)}

QMV had already been on various IGC agendas since the Single European Act. All Member States agreed that enlargement required its extension, but there was no consensus on the articles. The Commission's proposal to make QMV the general rule was considered by most as a non-starter. As a result, the IGC opted for an article-by-article approach (Galloway, 2001, pp. 99-100). The Portuguese presidency had already prepared the dossiers so that the positions 
Table 4: Flexibility

\begin{tabular}{|c|c|c|c|c|}
\hline Flexibility & Organizer & Broker & Political Leader & National Positions/Interest \\
\hline Dominant demand & $\begin{array}{l}- \\
\text { Old and transparent } \\
\text { topic }\end{array}$ & \begin{tabular}{l}
\multicolumn{1}{c}{+} \\
Some brokerage needed \\
Multiple brokerage \\
Majority in favour of \\
relaxation
\end{tabular} & Old topic ${ }^{-}$ & $\stackrel{+}{\text { Multiple brokerage }}$ \\
\hline Dominant supply & $\begin{array}{l}\quad \stackrel{+}{\text { Meetings were well }} \\
\text { prepared; issues were } \\
\text { clearly mapped out }\end{array}$ & $\begin{array}{l}\quad \stackrel{+}{\text { Chair developed }} \\
\text { compromises } \\
\text { Co-operation of chair with } \\
\text { Germany and Italy }\end{array}$ & 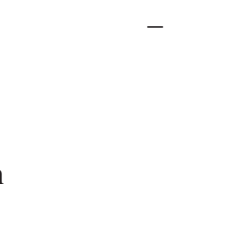 & $\begin{array}{l}\stackrel{+}{1}+ \\
\text { France favoured } \\
\text { relaxation but not } \\
\text { a priority }\end{array}$ \\
\hline$D=S$ & $\begin{array}{l}\text { Supply matched } \\
\text { demand }\end{array}$ & & & \\
\hline
\end{tabular}

Source: Authors' own data. 
of the various delegations were transparent. Having grouped the different provisions into categories such as 'provisions associated with the internal market', 'institutionally anomalous decisions' etc., Portugal had drawn up a list of approximately 50 articles for which QMV was acceptable (Galloway, 2001, p. 100). Taxation, social security, asylum and migration, common commercial policy, structural and cohesion funds, and the environment remained sensitive (Gray and Stubb, 2001, p. 16; Ludlow, 2001, pp. 15-17). One way out was to limit the extension of QMV to only parts of these articles.

Demand. The dossier primarily needed a broker who could master the technicalities and formulate compromise proposals whilst taking account of the various sensitivities. The chair was in a good position to assume this role. Moreover, there were other brokers - such as the Commission and some Member States - who were ready to contribute. The presence of multiple brokers offered scope for a French national position. Political leadership was not possible since QMV, as a general decision-making rule, had already been excluded during the Portuguese presidency. Given the extensive preparations under previous presidencies, task-oriented leadership had already been provided.

Supply. In general, France favoured further extension of QMV. As Portugal had already forged agreement on the 'easy' dossiers, France had to concentrate on the sensitive issues. The QMV dossier was largely dealt with at the level of the Vimont preparatory group in which the presidency emphasized brokerage. It listed the positions and tried to take into account the different national concerns - including the French. The attempts to forge agreement on social security and taxation were without result, despite strong support from the Commission (social security) and the German delegation (taxation). Denmark vetoed an agreement on social security and the taxation article was a bridge too far for several delegations.

In the case of the common commercial policy, France itself was the strongest opponent of QMV. This had to do with national sensitivities in cultural matters, audio-visual services and education. A big lobby group of actors and media personalities mobilized the press and exerted strong pressure on the government not to let down French and European culture. Given the high visibility, neither Chirac nor Prime Minister Jospin wanted to be seen as too soft. At the same time, several other delegations pushed hard for QMV in trade.

$D=S$ ? First and foremost, the dossier demanded a broker. The presidency played a key role in formulating compromises - except in the case of trade. The lack of progress in the sensitive areas was primarily due to the intransigent positions of the Member States. However, key actors also believe that the chair 
Table 5: QMV

\begin{tabular}{|c|c|c|c|c|c|}
\hline$Q M V$ & Organizer & \multicolumn{2}{|c|}{ Broker } & Political Leader & $\begin{array}{c}\text { National Positions } \\
\text { Interests }\end{array}$ \\
\hline Dominant demand & $\begin{array}{l}\stackrel{-}{\text { Old and transparent }} \\
\text { topic }\end{array}$ & $\begin{array}{c}\stackrel{+}{\text { Sensitive issue }} \\
\stackrel{-}{\text { Multiple brokerage }}\end{array}$ & $\begin{array}{l}\stackrel{+}{\text { Sensitive issue }} \\
\stackrel{-}{\text { Multiple brokerage }}\end{array}$ & $\begin{array}{l}\quad- \\
\text { Old topic; option to } \\
\text { make QMV the } \\
\text { general rule was a } \\
\text { non-starter }\end{array}$ & $\begin{array}{l}\stackrel{+}{\text { Scope for national }} \\
\text { position because of } \\
\text { multiple brokerage }\end{array}$ \\
\hline Dominant supply & $\begin{array}{l}\quad+ \\
\text { Meetings were well } \\
\text { prepared; issues were } \\
\text { mapped out clearly }\end{array}$ & $\begin{array}{l}\quad+ \\
\text { Chair played key } \\
\text { role in developing } \\
\text { compromises }\end{array}$ & $\begin{array}{l}\quad- \\
\begin{array}{l}\text { France did not } \\
\text { broker }\end{array} \\
\text { Brokerage by } \\
\text { Commission and } \\
\text { Finland }\end{array}$ & - & $\begin{array}{l}\quad+ \\
\text { Important for France } \\
\text { and its political top, } \\
\text { especially in the } \\
\text { case of trade }\end{array}$ \\
\hline$D=S$ & $\begin{array}{l}\text { France brokered heavi } \\
\text { ment but delayed the }\end{array}$ & $\begin{array}{l}\text { ly. The fact that Fran } \\
\text { negotiations, eating in }\end{array}$ & $\begin{array}{l}\text { was weak on brokera } \\
\text { the precious time of }\end{array}$ & $\begin{array}{l}\text { in the field of trade di } \\
\text { ce }\end{array}$ & not prevent an agree- \\
\hline
\end{tabular}

Source: Authors' own data. 
bears part of the responsibility, because in Nice it had insufficiently fostered the potential for progress. Chirac's brokerage positions were seriously hampered by his attempts to make friends by regularly giving in to other countries' demands, with the hope of safeguarding French interests on the reweighting of votes (see below).

As regards the trade dossier, France itself was the strongest opponent of an extension of QMV. When it appeared that the chair was incapable of distancing itself from its national position, the Commission and the Finnish delegation stepped in and hammered out an agreement. The defence of the French national position did not prevent a deal but it had delayed the negotiations. Precious time was lost in Nice on a dossier that should have been settled at a lower level. Moreover, it negatively affected trust in the presidency.

\section{Size of the Commission}

Having been on the agenda in Amsterdam, the positions of the different delegations regarding the size of the Commission were well known (transparent). The issue was highly sensitive because it was linked with the influence of Member States. The division between small and big delegations further complicated the situation and the atmosphere was one of distrust. Big countries wanted to be compensated for losing their second Commissioner and the small states feared that their Commissioners would rotate while the big countries would always be represented.

When France took over, two options - one Commissioner per country or a capped college - were still on the table. The first was supported by the small Member States (the majority). The second was preferred by most of the big countries and could well be argued from a European point of view: a small Commission would be more efficient and more independent.

Demand. The polarizing views in this dossier required ample brokerage. As the national delegations and the Commission were divided, brokerage had to be ensured primarily by the chair. Initially, there was no multiple brokerage. The option of a small and strong Commission lent itself to a leadership approach but, due to the sensitivity and distrustful atmosphere, careful preparation would have been needed. It meant moving discussions away from frictions between small and large, recasting the debate in a long-term perspective and ensuring trust. The fact that the model of a small Commission coincided with the French national position made such an approach all the more challenging.

Supply. France had already defended its preference for a small Commission in Amsterdam. The small countries saw the appeal for a 'small and effective' 
Commission as a way to push for its own preferred position. France did nothing to diminish these concerns. On the contrary, by initially refusing to inscribe the principle of equal rotation into the Treaty, it fuelled suspicions of a hidden agenda.

Contrary to flexibility and QMV, in which the permanent representation had taken the lead, this dossier was handled at the political level. Especially in the first months of the negotiations, the small Member States felt that France was not listening to their objections. At the first ministerial conclave of 24 July, the chair was accused of failing to take into account the views of the majority. This spoiled the atmosphere and the capped Commission was seen as an abuse of the presidency position. The Luxembourg Prime Minister Jean-Claude Juncker summarized the discussions as 'a crazy trench warfare between small and large Member States' (Bulletin Quotidien Europe, 2000, p. 5).

Nevertheless, it was in Biarritz that the first foundations for a compromise between small and big Member States emerged (Gray and Stubb, 2001, p. 12). The Dutch proposal to postpone the introduction of a small Commission was an important breakthrough. Following the models of the Council Secretariat for rotation on an equal basis, France accepted that this principle be written into the Treaty and convinced the other big countries to follow. Deferred capping and equal rotation also convinced some of the smaller countries.

$D=S$ ? The dossier demanded a broker and had potential for political leadership. Given the earlier rounds of negotiations, the role of organizer was not so necessary. Giving it the benefit of the doubt, it can be argued that, by pushing for a small and independent Commission, France had tried to provide political leadership. Due to a lack of preparation and strategy, it did not succeed, however, in elevating the debate in terms of what is best for the EU. As a corollary, its behaviour was perceived as a defence of the national position. The broker role was assumed only during the last months of the negotiations and was triggered by proposals from the Netherlands and the Council Secretariat. This ultimately led to a more ambitious outcome than many had expected (Galloway, 2001, p. 57).

\section{Reweighting of Votes}

The reweighting of votes in the Council had been a stumbling block in Amsterdam and was also the most sensitive question in the IGC 2000. It is a typical example of zero-sum negotiations: more votes for one Member State imply a decrease in the relative position of others. Moreover, big countries wanted sufficient compensation for the loss of their second Commissioner while the small ones were afraid of becoming marginalized in an enlarged EU. 
Table 6: Size and Composition of the Commission

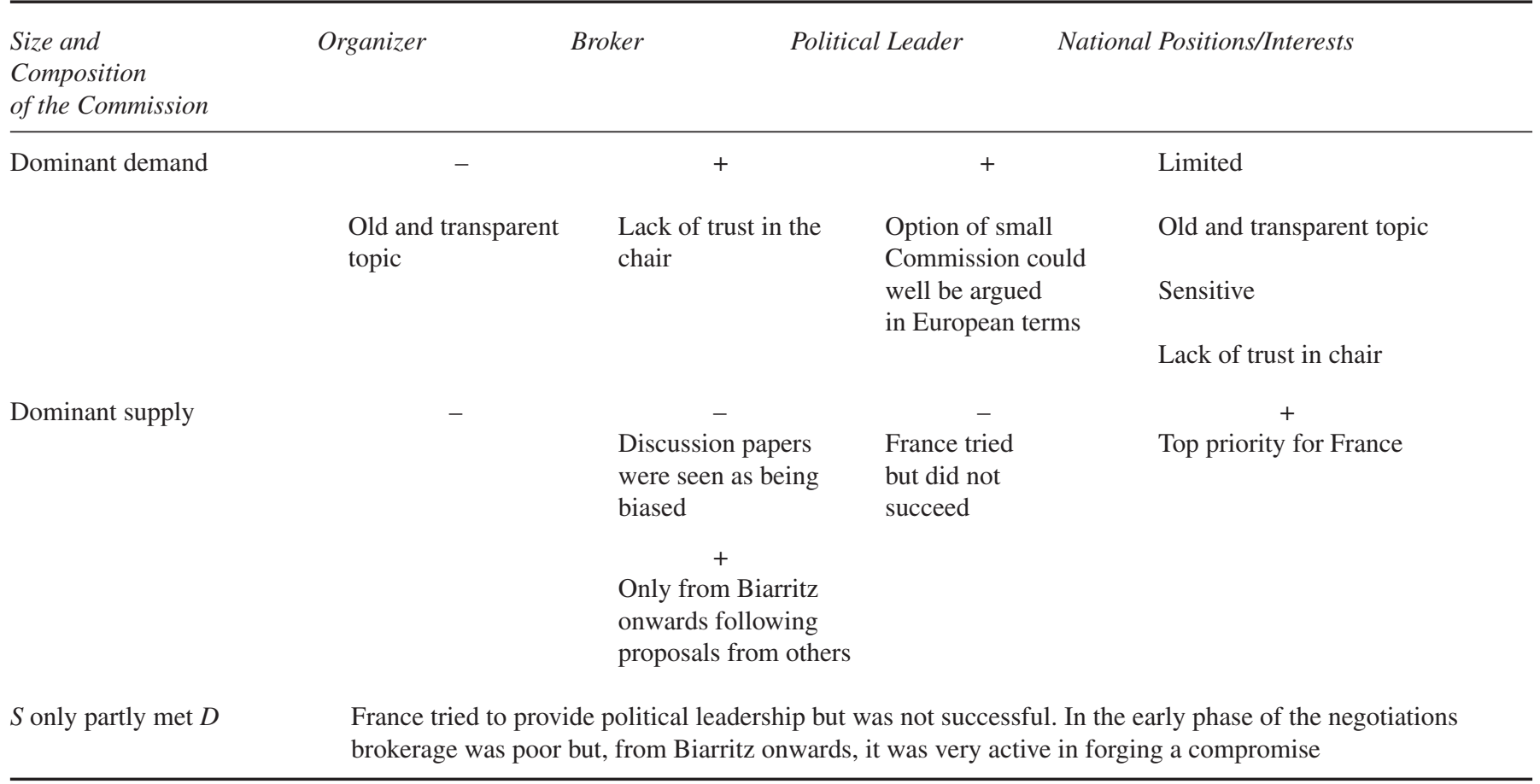

Source: Authors' own data.

France tried to provide political leadership but was not successful. In the early phase of the negotiations brokerage was poor but, from Biarritz onwards, it was very active in forging a compromise 
Demand. This dossier was undoubtedly the most challenging and was an example of conflicting pulls. Lack of trust in the chair, absence of multiple brokerage, and the shadow of the future (failure would obstruct enlargement) gave a pull towards group-oriented leadership. The sensitivity of the issue made it all the more important to invest in a good atmosphere. At the same time, there were factors restricting the scope for brokerage. Arguments had been repeated over and over again (old topic) and Member States would not make major concessions prior to Nice. It was a typical case where agreement would be reached only under pressure of a deadline and a waiting press.

The dossier did not demand a political leadership approach. Member States were so obsessed with securing their own interests that, according to insiders, elevating the debate to a discussion on principles was a non-starter.

There was some scope for the representation of national interest. For any country in the chair, the interests at stake were too high simply to be ignored. The lack of trust in the chair and the absence of other brokers implied, however, that France had to handle the defence of its national position carefully.

Supply. France had two main priorities. It wanted to reinforce the position of the big Member States who had given up their second Commissioner and it wanted parity with Germany. The latter question was widely discussed in the French press. Neither coalition party wanted to be seen as selling out to the French interests. They observed each other closely, ready to take political advantage whenever the other gave in. This manœuvred Paris into a difficult situation vis$\grave{a}$-vis both its own public and its partners. No attempts were made to explain to the French public that Germany's size would justify some differentiation. The obsession with parity raised suspicion with the other delegations. They feared that the first objective was to secure a good deal for France.

The push for a simple reweighting of votes while refusing to consider seriously the option of double majority reinforced the misgivings. Despite bilateral summits, France did not manage to settle the parity issue with Germany prior to Nice.

$D=S$ ? The weighting of votes dossier was subject to conflicting pulls. Its sensitive character, together with the lack of multiple brokerage and trust in the chair demanded group leadership. At the same time, the scope for brokerage was restrained because it was a topic that had already been extensively discussed in Amsterdam and Member States would postpone concessions until the final moments of Nice. There was some room for national interests but in the light of distrust towards the chair it had to be handled carefully. In terms of supply, France invested little in group leadership and did not handle its national interest well. Rather than being a facilitator the chair was one of the central problems 


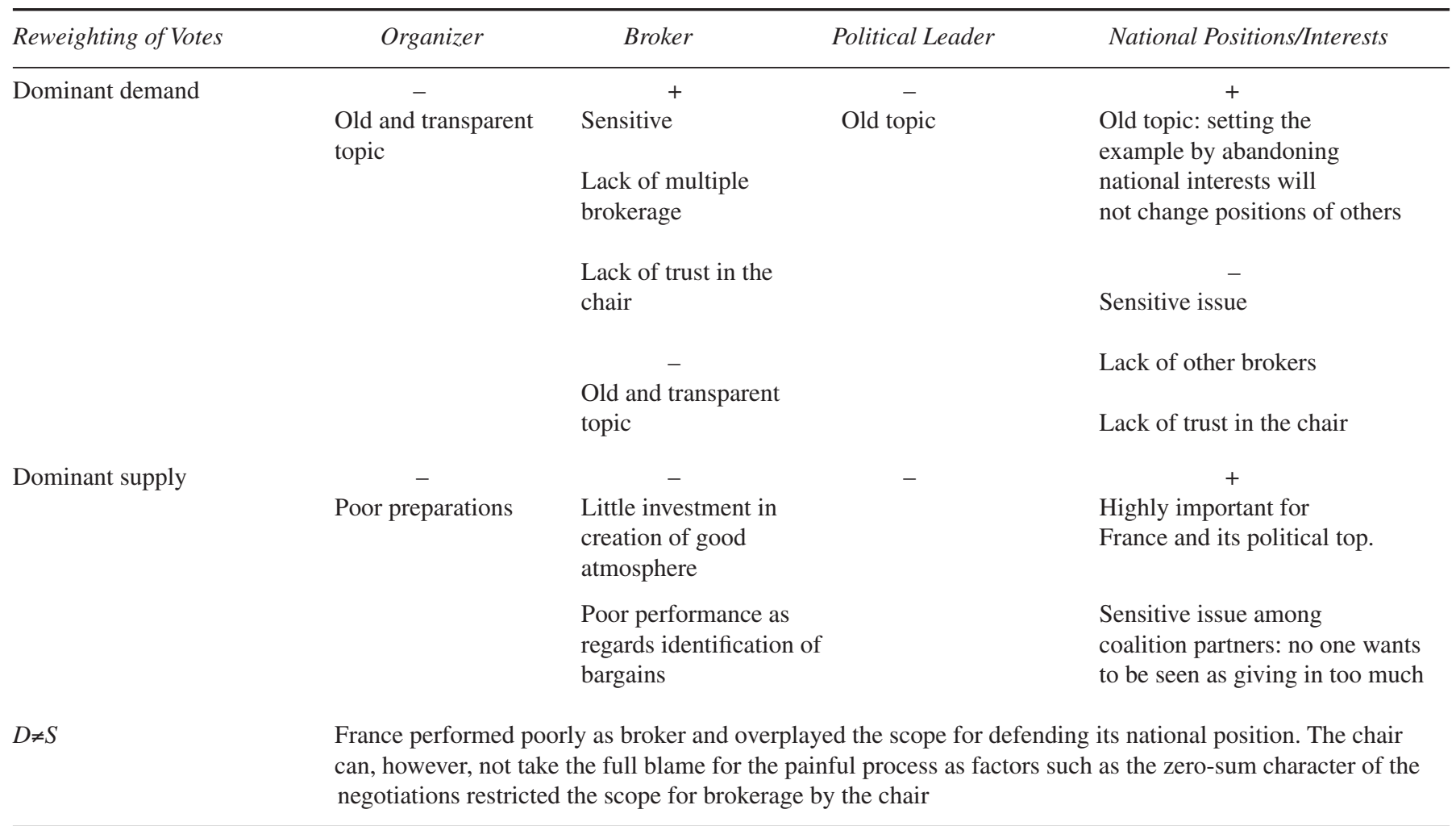

Source: authors' own data. can, however, not take the full blame for the painful process as factors such as the zero-sum character of the negotiations restricted the scope for brokerage by the chair 
at the summit and had to spend valuable time on working out a compromise with Germany. Its proposal to maintain parity between France and Germany but to differentiate between the Netherlands and Belgium further eroded its credibility. Spain, among others, cleverly exploited the situation by extracting as many concessions as possible. As mentioned before, it also affected the presidency's position in the QMV negotiations. In the end agreement was reached. This had to do not so much with the performance of the chair but with the fact that no one wanted to be blamed for a failure at Nice.

\section{Conclusion}

Presidencies are central yet slightly invisible actors in EU decision-making. Better understanding of their influence and behaviour has to start by making presidency roles explicit and by specifying the situational variables that influence their choices. Moreover, new governance tools are needed if past frustrations with presidencies are to be avoided. Ex post evaluations can be such a tool. In addition, countries invest heavily in presidencies. They therefore deserve fair assessments - not just reports strongly influenced by the heat of the moment.

This article developed an evaluation model based on contingency theory. It started from the assumption that chairs fulfil four roles (Table 1). Secondly, it stated that the demand and the supply of roles depend on the environment. Using this model, the question is not whether the chair was well-organized or created a good atmosphere, but whether demand equalled supply. To elaborate the contingency theory we formulated hypotheses on how the external and internal conditions influence the demand and supply of the four presidency roles (Tables 2 and 3). The model was tested on the French presidency during the IGC 2000 - a presidency that was unreservedly criticized for being badly organized, poorly brokered and too centred on its national interests.

The study underlines that the presidency has too many dimensions not to have a systematic evaluation mechanism. Compared to the general condemnation of the French presidency, the contingency approach offers a broader set of conclusions. Our analysis indicates that there was no dominant demand for task-oriented leadership during the IGC 2000. The agenda points had already been discussed extensively both in Amsterdam and under the preceding presidencies and the countries had stated their positions.

As regards brokerage, the chair did well in the issues of flexibility and QMV. In the Commission dossier, the poor initial performance was compensated for in the weeks before the summit. The chair's brokerage role in the reweighting of votes was, however, problematic. Rather than identifying bargains, the chair was primarily concerned with its own problems. 
The IGC 2000 offered little scope for transformational leadership. It involved old issues and the directions for solutions had already largely emerged under the previous presidencies. The composition of the Commission was an exception. However, the French failed to sell the capped Commission as being in the EU's interest. By ignoring the sensitivities of the smaller countries it reinforced the suspicion that Chirac was using the chair to his own advantage.

The way France handled its national position and interests was problematic in two of the four cases. By focusing on a capped Commission, it failed to convince its partners of the strengths of this option. In the reweighting of votes, France proposed a solution to Belgium that it would not itself accept. It was not the chair's national preferences which were problematic, but the way in which it handled them.

This summary shows that the critique of the French chair was both only partly justified and accurate. It disregarded the dossiers that were handled well and, by ignoring the environment in which the chair operated, the critique was not always justified.

In many evaluations of the French presidency, organization was a key criterion. However, in the case of the IGC 2000, this role was not so crucial. The four agenda items were old and had already been mapped out by previous presidencies. The charge of poor brokerage ignores the presence of multiple brokerage and hence makes it seem more serious than it was during the negotiations. Transformational leadership is missing in most evaluations. France tried to provide it in the Commission dossier but, due to poor preparations and strategy, it was not successful. The critique of its national interests is overstated. In principle, there was some room for national positions. However, France should have played its cards much better. The usefulness of the approach developed in this article is underlined by the more detailed insight and the resulting qualifications to the general condemnation of the French organization and bias. Some of the criticism is justified, but there are also strong points. This underlines the danger of poor evaluations of such a key actor in EU decision-making. 
Correspondence:

Adriaan Schout

European Institute of Public Administration

PO Box 1229

NL-6201 BE Maastricht

The Netherlands

Tel: +31 433296319

email: a.schout@eipa-nl.com

Sophie Vanhoonacker

Faculty of Arts and Social Sciences

University of Maastricht

PO Box 616

NL-6200 MD Maastricht

The Netherlands

Tel: +31 433883242

email: s.vanhoonacker@politics.unimaas.nl

\section{References}

Ansoff, I. (1985) Corporate Strategy (London: Penguin).

Barbé, E. (2003) 'The Spanish Presidency: Catalysing a New Axis in the EU'. Journal of Common Market Studies Annual Review of the European Union, Vol. 41, pp. 45-8.

Bulletin Quotidien Europe (2000). No 7821, 15 October.

Child, J. (1972) 'Organizational Structure, Environment and Performance: The Role of Strategic Choice'. Sociology, Vol. 6, No.1, pp. 1-22.

Child, J. (1975) 'Managerial and Organizational Factors Associated with Company Performance. Part II : A Contingency Analysis'. Journal of Management Studies, Vol. 12, No.1, pp. 12-27.

Chirac, J. (2000) 'Notre Europe: Discours prononcé par Monsieur Jacques Chirac, Président de la République Française devant le bundestag allemand'. Berlin, 27 June.

Costa, O., Couvidat, A., Daloz, J.-P. (2003) 'The French Presidency of 2000: An Arrogant Leader?'. In Elgström, O. (ed.) European Union Council Presidencies. A Comparative Perspective (London: Routledge).

Dimitrakopoulos, D.G. and Pappas, A.G. (2004) 'The Greek presidency: In the Shadow of War'. Journal of Common Market Studies, Vol. 42, No. 1, pp. 43-6.

Dinan, D. (1999) Ever Closer Union? An Introduction to the European Community (Boulder, CO: Lynne Rienner).

Elgström, O. (2002) 'Evaluating the Swedish Presidency'. Co-operation and Conflict, Vol. 37, No. 2, pp. 183-9.

Elgström, O. (ed.) (2003) European Union Council presidencies. A Comparative Perspective (London: Routledge). 
Elgström, O. and Jönsson, C. (2000) 'Negotiating in the European Union: Bargaining or Problem Solving'. Journal of European Public Policy, Vol. 7, No. 5, pp. 684-704.

European Council (1979) 'Report of the Three Wise Men: Report on European Institutions, Presented by the Committee of Three to the European Council' (Luxembourg: OOPEC).

European Council (1997) Council Guide Vol. 1. Presidency Handbook (Luxembourg: OOPEC).

European Council (2002) 'Council Decision of 22 July 2002 adopting the Council Rules of Procedure'. Official Journal L.230/7-26, 28 August.

Friis, L. (2003) 'The Danish Presidency: Wonderful Copenhagen'. Journal of Common Market Studies Annual Review of the European Union, Vol. 41, pp. 49-51.

Galbraith, J.R. (1973) Designing Complex Organizations (Reading: AddisonWesley).

Galloway, D. (2001) The Treaty of Nice and Beyond. Realities and Illusions of Power in the EU (Sheffield: Sheffield Academic Press).

Gibson, K., Thompson, L. and Bazerman, M. (1996) 'Shortcomings of Neutrality in Mediation: Solutions Based on Rationality'. Negotiation Journal, Vol. 12, No. 1, pp. 69-80.

Gray, M. and Stubb, A. (2001) 'Keynote Article: The Treaty of Nice - Negotiating a Poisoned Chalice?' Journal of Common Market Studies Annual Review of the European Union, Vol. 39, pp. 5-23.

Hayes-Renshaw, F. and Wallace, H. (1997) The Council of Ministers (New York: Macmillan).

IEEP (2005) Exploration of Options for the Implementation of the Open Method of Co-ordination for Environmental Policy (Brussels: Institute for European Environmental Policy).

King, G., Keohane, R. and Verber, S. (1994) Designing Social Enquiry: Scientific Inference in Qualitative Research (New Jersey: Princeton University Press).

Kirchner, E. (1992) Decision-making in the European Community: The Council Presidency and European Integration (Manchester: Manchester University Press).

Lawrence, P. and Lorsch, J. (1969) Organization and Environment: Managing Differentiation and Integration (Homewood: R.D. Irwin).

Ludlow, P. (1995) Preparing for 1996 and a Larger European Union: Principles and Priorities (Brussels: Centre for European Policy Studies).

Ludlow, P. (2001) 'The European Council at Nice: Neither Triumph nor Disaster, A View from Brussels'. A Commentary on the EU, No.10 (Brussels: Centre for European Policy Studies).

O'Nuallain, C. (ed.) (1985) The Presidency of the European Council of Ministers: Impacts and Implications for National Governments (London/Maastricht: Croom Helm/European Institute of Public Administration).

Powell, V. (1987) Improving Public Enterprise Performance: Concepts and Techniques (Geneva: International Labour Office). 
Quaglia, L. (2004) 'The Italian Presidency'. Journal of Common Market Studies Annual Review of the European Union, Vol. 42, pp. 47-50.

Schout, J.A. (1998) 'The Presidency as Juggler: Managing Conflicting Expectations'. Eipascope, No. 2, 1998, pp. 2-10.

Schout, J.A. (2004) 'The Rotating Presidency: Governance without Governance'. Paper presented at the'2004 Maastricht Forum on European Integration - Making the Constitution Work'. European Institute of Public Administration (EIPA), Maastricht, 19 November.

Schout, J.A. and Vanhoonacker, S. (2005) 'Nice and the French Presidency'. In Laursen, F. (ed.) The Treaty of Nice: Actor Preferences, Bargaining and Institutional Choice (Dordrecht: Martinus Nijhoff).

Sherrington, P. (2000) The Council of Ministers - Political Authority in the European Union (London/New York: Pinter).

Tallberg, J. (2003) 'The Agenda-Shaping Powers of the EU Council Presidency'. Journal of European Public Policy, Vol. 10, No.1, pp. 1-19.

Trumpf-Piris Report (1999) Operation of the Council with an Englarged Union. SN 2139/99 (Brussels: Secretary-General of the Council of the European Union).

Vanhoonacker, S. and Schout, A. (2003) 'The Reform of the Presidency: Towards a Third Life of the EU Presidency?' Paper presented at the EUSA 8th Biennial International Conference, 27-9 March, Nashville, Tennessee.

Vanhoonacker, S. and Schout, A. (2002). 'The Presidency Matters: The Dutch Presidency and Schengen'. Mimeo (Maastricht: European Institute of Public Administration).

Westlake, M. (1999) The Council of the European Union (London: John Harper).

Weyland, J. (1993) 'Strategies and Perspectives of the Luxembourg Presidency'. In Kirchner, E. and Tsagkari, A. (eds) The EC Council Presidency. The Dutch and Luxembourg Presidencies (London: University Association for Contemporary European Studies).

Wurzel, R. (2004) The EU Presidency: 'Honest Broker' or Driving Seat? An AngloGerman Comparison in the Environmental Policy Field (London: Anglo-German Foundation).

Yukl, G. (1998) Leadership in Organizations. 4th edn (Upper Saddle River, NJ: Prentice Hall). 